DigitALCOMMONS @WAYNESTATE —

\section{Michigan Journal of Counseling: Research, Theory and Practice}

Volume $39 \mid$ Issue 2

Article 5

$1-1-2013$

\title{
Our New Editor
}

Jennifer Bornsheuer

Oakland University

Follow this and additional works at: https://digitalcommons.wayne.edu/mijoc

\section{Recommended Citation}

Bornsheuer, J. (2013). Our New Editor, Michigan Journal of Counseling, 39(2), 45. doi:10.22237/mijoc/1356998640

This From the Editor is brought to you for free and open access by the Open Access Journals at DigitalCommons@WayneState. It has been accepted for inclusion in Michigan Journal of Counseling: Research, Theory and Practice by an authorized editor of DigitalCommons@WayneState. 


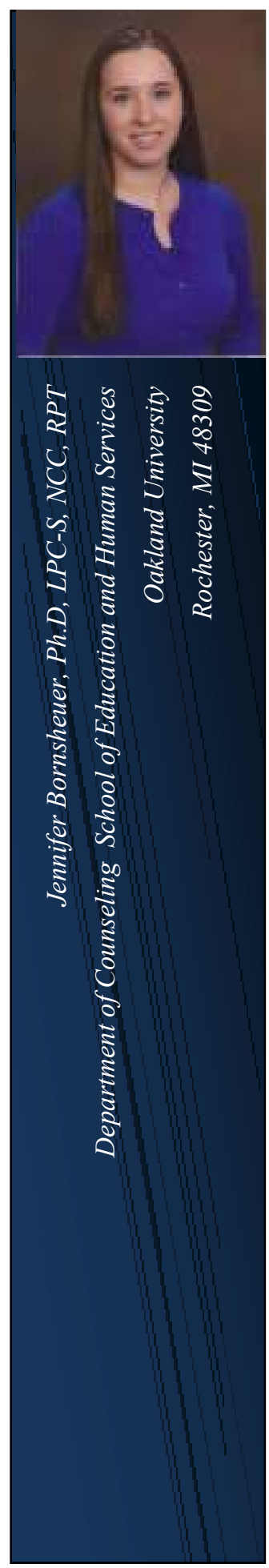

\section{OUR NEW EDITOR}

Dr. Jennifer Bornsheuer is the new Assistant Professor in the Counseling Department at Oakland University. In 2005, she received her B.A. in Psychology from the University of North Texas and then her M.S. in Counseling and Development from Texas Woman's University in 2007. Recently, she completed her Ph.D. in Counselor Education from Sam Houston State University in 2012. The title of her dissertation was "Conservative Christian Parents Perceptions of Child Parent Relationship Therapy."

Dr. Bornsheuer has over 5 years of clinical experience working with children, adolescents, and families in community settings. Her research interests include the use of Child Parent Relationship Therapy (CPRT) with children and parents, the use of play therapy and filial therapy with children who have experienced trauma, the inclusion of religious and spiritual beliefs in the counseling process and counseling programs, qualitative methodology, application of Adlerian theory and methods in supervision, and mentorship of women in graduate counseling programs. Dr. Bornsheuer has authored and co-authored numerous articles; made professional presentations at national, state, and local conferences; and has been very active in state and national counseling organizations. She has received several awards including the Emily Oe Counseling and Development Play Therapy Award and Scholarship, the Outstanding Practitioner Award from the Beta Kappa Tau chapter of Chi Sigma Iota, the Outstanding Counselor Educator Award - Doctoral Student, and the Excellence in Writing Award from Sam Houston State University. 